\title{
Correction to: The effect of $\mathrm{CO}_{2}$ and $\mathrm{N}_{2}$ on phase relations, fluid composition, and quartz solubility in amphibolite facies metamorphic rocks
}

\author{
Margaret V. Artimenko ${ }^{1}$
}

Published online: 25 October 2017

(c) Springer-Verlag GmbH Germany 2017

\section{Correction to: Contrib Mineral Petrol}

\section{(2016) 171:103}

DOI 10.1007/s00410-016-1313-1

The cell containing the values of $\mathrm{H} 0.015,0.020,0.025$ in Table 1 of the original paper is published incorrectly. The correct values are shown below.

H $0.15,0.20,0.25$

The values of bulk hydrogen in 8th line from below in second column of page 3 of the original paper are published incorrectly. The line with correct values is shown below.

when bulk hydrogen is $0.15,0.20$, and $0.25 \mathrm{~mol}$ 